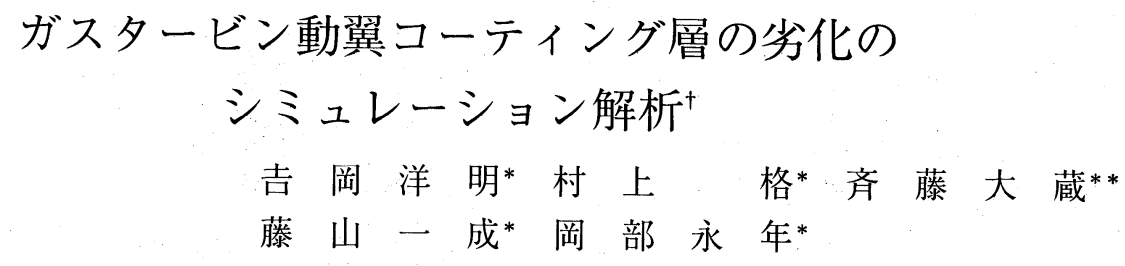

\title{
Simulation Analysis of Gas Turbine Bucket Coating Degradation
}

by

\section{Yomei Yoshioka*, Itaru Murakami*, Daizo SaIto** Kazunari FujIYAMA* and Nagatoshi OKABE*}

In order to clarify the degradation mechanism of gas turbine bucket coating, $25000 \mathrm{hr}$ serviced bucket with $\mathrm{Pt}-\mathrm{Al}$ coating was destructively evaluated. Degraded phase, which is called breaching, was identified in the substrate of the tip section of the bucket and was figured out to be an Al-rich phase. Based on this evaluation result, Monte Carlo simulation analysis was carried out to simulate the formation of breaching by using an Al-cluster diffusion model. The results obtained are as follows :

(1) The degradation phenomena in the serviced coated bucket were successfully simulated by using an $\mathrm{Al}$-cluster diffusion model in a simple $\mathrm{Ni}-\mathrm{Al}$ alloy system.

(2) By using this simulation method, inverse problem analyses of actual complex degradation phenomena were performed. The results are as follows;

(a) Preferential formation temperature of breaching was identified. (b) Effects of surface temperature and temperature gradient on the formation of breaching were identified. The gradient shifted the peak breaching formation temperature to the higher surface temparature and also increased the amount of breaching. (c) Effect of orientation on the probability of breaching formation was identified. The probability tended to be high at the direction of Al-cluster diffusion.

Key words : $\mathrm{Pt}-\mathrm{Al}$ coating, Breaching, Al-cluster, Bucket degradation, Simulation, Diffusion

\section{1 緒訔}

ガスタービンの高温部品は, $1000^{\circ} \mathrm{C}$ を超える高温 のガスを作動流体として用いることから, 非常に過酷 な環境下で使用されている. 特にタービンの初段動翼 は, 高い遠心応力と共に, 直接高温のガスに曝される ことから高温腐食／高温酸化も考慮する必要があり, 耐食コーティングを施し，用いられている.

動翼のコーティングは1960年代にジェットエンジン でアルミニウムの拡散処理が適用されて以来, 発電用 ガスタービンでも検討が行われ，耐高温腐食性と耐高 温酸化性に優れたコーティングの開発が行われている. この中でも白金-アルミニウム $(\mathrm{Pt}-\mathrm{Al})$ の拡散コー ティングは耐酸化性に加え，優れた耐高温腐食性を有 することから，発電用ガスタービンに広く用いられて きた. しかし, 近年の燃焼ガス温度の高温化に伴い, コーティング層の劣化は，運転中に顕著に生じるよう になってきており，このためリコーティングによるコ
ーティング層の再生処理も検討されるに至っている. このコーティング層の劣化は, ガスタービンの動翼の 寿命を考える場合，基材の劣化と同様に重要である. ここでは，このコーティング層の劣化の現象解析を， 約 $25000 \mathrm{hr}$ 運転した実機ガスタービンの初段動翼の 観察結果を基に行った。また，これに基づき，コー ティング層の劣化は, $\mathrm{Al}$ の基材への拡散に起因する ものと考え，Al クラスターの拡散モデルを用い，モ ンテカルロシミュレーションにより解析し, 検討を 行ったもので，その結果を以下に述べる.

\section{2 実機初段動翼の劣化・損傷調査}

\section{$2 \cdot 1$ 供試翼}

約 $25000 \mathrm{hr}$ 実機で運転を行った $1100^{\circ} \mathrm{C}$ 級ガスタ ービンの, Pt-Al コーティングを施した初段動翼を 本破壊調查に供した.

\section{$2 \cdot 2$ 調查方法}

供試翼のガス通路部から, 先端部, 中央部および付 


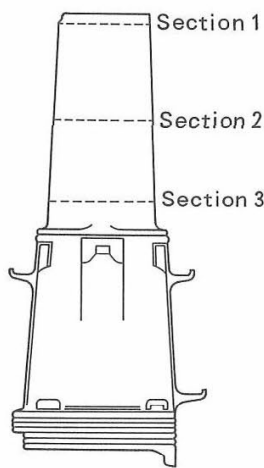

(a) Sectioning locations

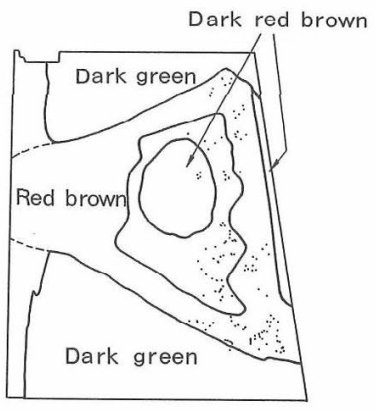

(b) Surface appearance (Suction side)

Fig. 1. Sectioning locations and bucket surface observation result.

け根部の 3 部位を, 翼の遠心応力方向に垂直な面で切 断し，その断面のコーティング層の調查を行った．切 断位置の概略図と調查翼翼面の外観観察結果を Fig. 1 に示す. 翼表面の外観観察結果からも推定できたが, 翼面の温度として最も高いのが翼中央部の第 2 断面で あり,ついで先端部の第 1 断面, 最も低いのが付け根 部の第 3 断面であった.

組織観察は切断面の表面を研磨後，エッチングを施 さずに，日本電子製 JCXA-840 型走查型電子顕微鏡 （SEM）にて，その反射電子像を用いて観察すると共 に, 各元素の分布の調査を, $\mathrm{X}$ 線マイクロアナライ ザー（EPMA）を用いた面分析により行った。

\section{$2 \cdot 3$ 調査結果および検討}

ガスタービンの動翼では, 高温ガスを作動流体とし て用いることから，酸化と硫化が相乗した，いわゆる 高温腐食の問題が生じていた。しかし，本調查対象の 供試動翼は，硫黄等の腐食生成物の含有量が少ない天 然ガスを燃料として用いていることから高温腐食は認 められず，高温酸化のみが認められた。

Fig. 2 に各断面の代表的なコーティング層の組織観 察結果を示す. 本調查に供したPt-Al コーティング は未使用状態では外表面から $\mathrm{PtAl}_{2}$ 相と NiAl 相の混 合層, NiAl 相，拡散層の 3 層構造を呈している。 た，最表層部には識別は困難であるがち密な $\mathrm{Al}_{2} \mathrm{O}_{3}$ の) 薄い酸化被膜が形成されており, 内部酸化あるいは硫 化を防いでいる。ここでは，表面温度が最も低い第 3 断面が，未使用状態に近い組織を呈していた。これに 対して第 2 断面は，表面温度が最も高いことからコー ティング層の劣化は最も著しく, 拡散層の形状の崩れ, すなわち, 組織境界の不明暸化と, コーティング層内 の $\mathrm{Al}$ 濃度の低下に起因する塊状の $\mathrm{Ni}_{3} \mathrm{Al}$ 相の析出が 生じていた。

これに対し，第 1 断面の温度は，第 2 断面と第 3 断

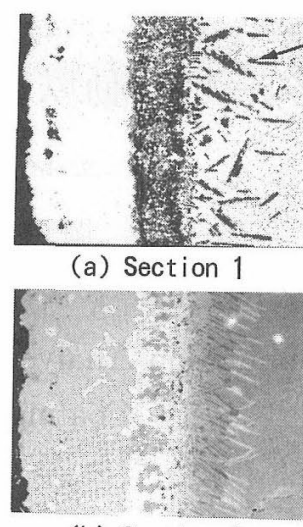

(b) Section 2
Breaching

$20 \mu \mathrm{m}$

$\mathrm{PtAl}_{2}+$ NiAl Diffusion zone

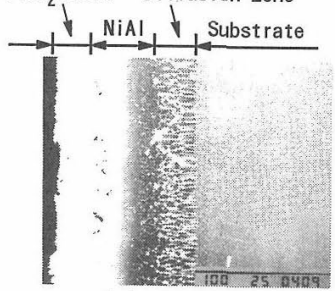

(c) Section 3
Fig. 2. SEM observation results of $\mathrm{Pt}-\mathrm{Al}$ coating at the three sections of the $25000 \mathrm{hr}$ serviced bucket.

面の中間である。ここでは，板状の劣化相が基材部に 生じて扔り，その周辺では，析出強化相である $\gamma^{\prime}$ 相 $\left(\mathrm{Ni}_{3} \mathrm{Al}\right)$ の消失が認められた。この板状の劣化相を 以下ブリーチングと呼び，コーティング層が劣化しそ の影響が基材にまで及んたこことを示す一つの指標とし て用いだ

Fig. 3 にEPMA による上記第 1 断面と第 3 断面の $\mathrm{Ni}$ と $\mathrm{Al}$ の面分析結果を示す。ほぼ未使用組織に近い 第 3 断面においては，Al がコーティング層と一部拡 散層に濃く認められるのに対し，第 1 断面では基材側 への拡散による濃度低下が認められ，加えて，ブリー チング部に $\mathrm{Al}$ の富化と, それに伴う $\mathrm{Ni}$ 濃度の低下 が認められた。ここでは，Cr，Tiあるいはその他の 元素濃度の富化は検出できなかった，また，酸素も検 出されておらず，酸化物ではなかったことから， Ni-

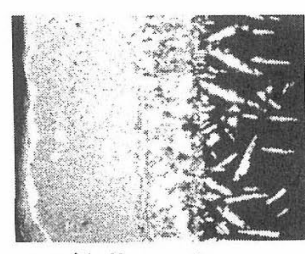

$\mathrm{Al}-\mathrm{X}$-ray Image

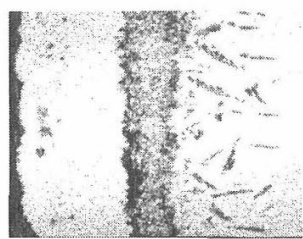

$\mathrm{Ni}-\mathrm{X}$-ray Image (a) Section 1

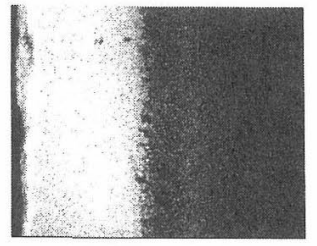

Al-X-ray Image

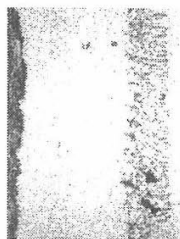

$\mathrm{Ni}-\mathrm{X}$-ray Image (b) Section 3

Fig. 3. EPMA analysis results of $\mathrm{Pt}-\mathrm{Al}$ coating at the (a) sections 1 and (b) 3 in the $25000 \mathrm{hr}$ serviced bucket. 
$\mathrm{Al}$ 系の状態図からこのブリーチングは $\mathrm{Al}_{3} \mathrm{Ni}$ と推定 した.

\section{3 シミュレーション手法に基づくコーティ ング層の劣化現象の解析}

本調査結果から $25000 \mathrm{hr}$ までの運転ではコーティ ング層は良好な耐酸化性を示しており, 顕著な酸化が 認められていない．しかし，コーティング層中の $\mathrm{Al}$ 濃度は低下し，かつ基材の一部に劣化相であるブリー チングの形成と, その周辺で, 強化相である $\gamma^{\prime}$ 相の 消失も認められた。いずれの現象も $\mathrm{Al}$ の基材への拡 散に起因している。ここではコーティング層の劣化評 価のパラメータとして, 基材に形成されたブリーチン グに着目し，このブリーチングの形成をシミュレー ションする手法についての検討を行った.

\section{$3 \cdot 1$ シミュレーション方法}

ブリーチングの形成は，コーティング層と基材の間 の $\mathrm{Ni}$ と $\mathrm{Al}$ の相互拡散と金属間化合物の形成・分解 に支配されている．基材合金は， $\mathrm{Ni}$ 基の合金であり Al の他にも Cr, Co, Ti， W, Mo, Ta, Nb, B, $\mathrm{Zr} ， \mathrm{C}$ を含有する高合金であるが，ここでは， $\mathrm{Ni}^{-}$ $\mathrm{Al}$ の単純な 2 元系合金を考え, 検討を行った.

ここではコーティング層は $\mathrm{NiAl}$ の金属間化合物, 基材は $\mathrm{Ni}$ の固溶体とし，拡散層はこの 2 相の混合組 織とし，モデルを構成した． $\mathrm{Al}$ は運転時間とともに 基材側に拡散し，基材中の $\mathrm{Ni}$ はコーティング層側に 拡散する.この拡散過程は $\mathrm{Al}$ 原子の拡散過程に律速 され，拡散速度は下記式 (1) で示す Fick の第 2 法則に 従うとした.

$$
\frac{\partial C_{\mathrm{Al}}}{\partial t}=\frac{\partial}{\partial X}\left(\tilde{D} \frac{\partial C_{\mathrm{Al}}}{\partial X}\right)
$$

\section{ただし，}

$\partial C_{\mathrm{Al}}$ : 平均 $\mathrm{Al}$ モル濃度, $\tilde{D}$ : 拡散係数

$t:$ 運転時間, $X:$ 表面からの距離

表面からの距離 $X$ での時刻 $t$ における $\mathrm{Al}$ の平均濃 度は, 式 (1)の拡散方程式を数值解析することにより, 求めることができる．数值解析に当たっては， $X$ $=210 \mu \mathrm{m}$ までをモデル化した. $\mathrm{NiAl}$ 中の $\mathrm{Al}$ 濃度は 平衡状態図で $\mathrm{NiAl}$ の金属間化合物を形成する濃度範 囲（40 60 mol\%）にあると仮定した.Fig. 4 に初期

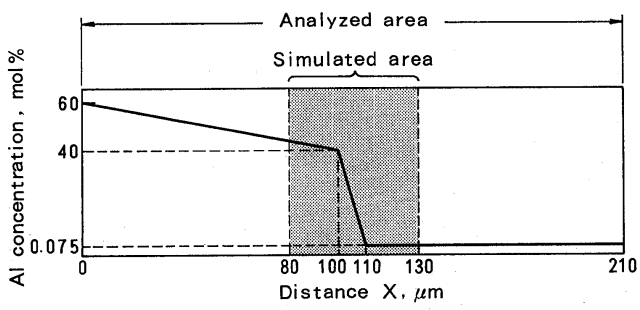

Fig. 4. Initial distribution of Al-cluster concentration for the simulation model.

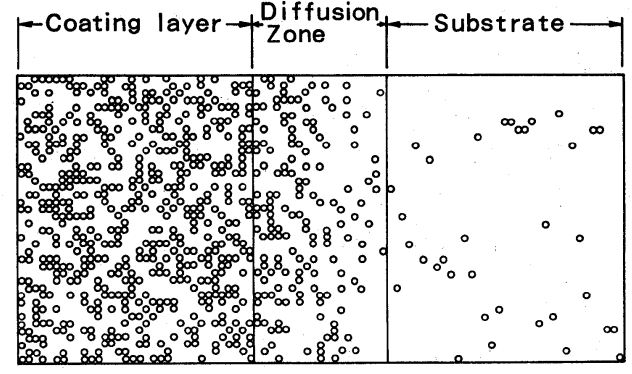

Fig. 5. Al-cluster distributions displayed at the initial condition of $88 \times 40$ cluster area.

$\mathrm{Al}$ 濃度分布を示す．外表面（X=0 $\mu \mathrm{m} ）$ を $60 \mathrm{~mol} \%$, 拡散層とに界面 $(X=100 \mu \mathrm{m})$ を $40 \mathrm{~mol} \%$ とし，そ の間を線形補間した、コーティング層および拡散層の 厚さは，実機翼のコーティング層を観察した結果から， それぞれ $100 \mu \mathrm{m}, 10 \mu \mathrm{m}$ とし，また，基材の $\mathrm{Al}$ 濃度 は，この翼材の成分規格值を用い， $0.075 \mathrm{~mol} \%$ とし た. 境界条件は, (1)基材深部（ $X \geqq 210 \mu \mathrm{m})$ では, $\mathrm{Al}$ 濃度は初期状態から変化しない, (2)外表面から外 気への $\mathrm{Al}$ の流出はない, と仮定し, 式 (2)のように 決めた.

$$
\left.\frac{\partial C_{\mathrm{Al}}}{\partial X}\right|_{X=0}=0,\left.C_{\mathrm{Al}}\right|_{X=\ell}=0.075
$$

式 (1) 中の拡散倸数 $\tilde{D}$ の值は材質と使用温度の関数と して与えられる.ここでは $\mathrm{Ni}$ 中の $\mathrm{Al}$ の拡散係数で ある下記值を用いた。

$$
\tilde{D}=D_{0} \exp \left(-2.6 \times 10^{5} / R T\right),\left(\mathrm{m}^{2} / \mathrm{sec}\right)
$$

ただし， $\boldsymbol{R}$ : ガス定数， $T$ : 温度 $(\mathrm{K})$,

$D_{0}:$ 頻度係数 $\left(1.0 \times 10^{4} \mathrm{~m}^{2} / \mathrm{sec}\right)$

この $\mathrm{Al}$ の拡散挙動をシミュレートするため, Fig. 5 に示すクラスタモデルを作成した．ここでは，平面 内での 2 次元の拡散を考え, 1 辺が $5 \times 10^{-7} \mathrm{~m}$ の矩形 領域を 1 個のクラスタとして, $\mathrm{X}$ 軸方向に 88 クラス 夕，Y 軸方向に 40 クラスタの大きさの領域をモデル

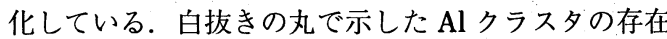
確率が平均濃度と等しくなるよう乱数を発生させ，ラ ンダムに配置している．また，拡散層と基材の境界も 乱数を用いて決定した.

$\mathrm{Al}$ クラス夕は，相互拡散により， $\mathrm{X}$ 軸に平行な方 向, あるいは $45^{\circ}$ の方向の最隣接の $\mathrm{Ni}$ クラス夕と置 換する.この置換は，式(1)により得られた $\mathrm{Al}$ の拡 散量の積算值が濃度を超えた場合に生じるものとし， 置換される $\mathrm{Al}$ クラスタおよびNi クラスタは乱数に より決定した。

ブリーチングは, 調查結果から $\mathrm{Al}_{3} \mathrm{Ni}$ と考え, そ の形成は，Al クラスタが拡散により基材に流入し， 3 個連続した場合に，ある確率を持って遷移するもの としたなおここの遷移確率は, シミュレーションに 
より形成したブリーチングの量が，実機で観察された 形成量と一致するように与えた。そして，いったんブ リーチングを形成するとそれ以後そのクラス夕は相変 化も拡散もせず，また，このブリーチングを横切る移 動もしないものとした.

この遷移確率には以下の式で示す温度依存性を与え ている.

$$
\begin{gathered}
\quad V=V_{0} \exp \left(-\frac{Q_{d}-Q_{p}}{R T}\right) \\
\text { ここで } \\
V: \text { ブリーチングへの遷移確率 } \\
Q_{d}: \mathrm{Al} \text { クラスターの拡散エネルギー } \\
Q_{p}: \text { ブリーチング生成エネルギー }
\end{gathered}
$$

ここでは, ブリーチングの形成は, $\mathrm{Al}$ クラスター の会合確率とブリーチングの形成確率により決まるも のと考えており, 温度が上がると会合確率は $\mathrm{Al}$ の拡 散量が大きくなることから高くなるが, 逆に, 形成確 率は低くなるとしている.

\section{$3 \cdot 2$ シミュレーション結果および考察}

$3 \cdot 2 \cdot 1$ ブリーチング形成の温度依存性 Fig. 6 は, $25000 \mathrm{hr}$ 運転に供した本調査翼の各断面のシ

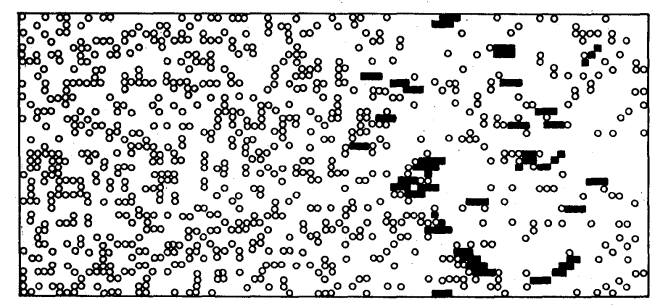

(a) Section 1

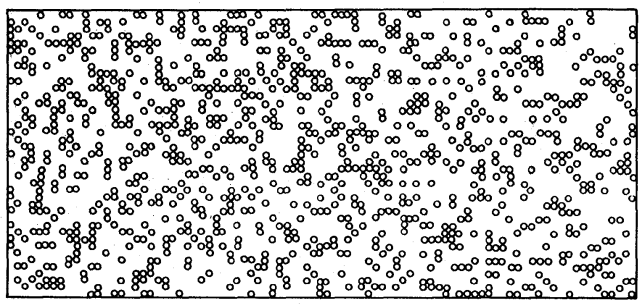

(b) Section 2

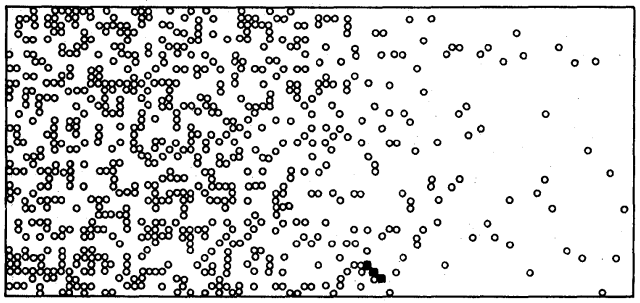

(c) Section 3

Fig. 6. Simulation results of Al-cluster diffusion and breaching formation at $25000 \mathrm{hr}$.
Table I. Variables used for simulation analysis.

\begin{tabular}{l|c|c|c}
\hline \multicolumn{1}{c|}{ Test sections } & 1 & 2 & 3 \\
\hline Surface temp. $\left({ }^{\circ} \mathrm{C}\right)$ & 850 & 900 & 750 \\
\hline Gradient $\left(\times 10^{5}{ }^{\circ} \mathrm{C} / \mathrm{m}\right)$ & -9 & -9 & -9 \\
\hline
\end{tabular}

ミュレーション結果を示す.この解析に用いた各部位 の表面温度を Table I に示す. 本翼は冷却翼であるこ とから，Table I に併記した温度勾配をいずれの断面 にも与えた.ここで用いた温度勾配は，翼表面から中 心部の冷却孔まで直線的に低下するものと仮定して設 定した. Fig. 6の白抜きの丸は Al クラス夕を, 連続 した 3 個の黒四角はブリーチングクラスタを示す. 最 も温度の高い第 2 断面 (b) は, Al クラス夕の拡散速度 が早いため, 基材への流入量は大きいが, 逆にブリー チングの形成確率は低下する。この結果，本部位では ブリーチングの形成は認められていない，また，温度 の低い第 3 断面においては，逆に形成確率は高いが, $\mathrm{Al}$ クラスタの流入量が少ないことから, 一つの例外 を除きブリーチングの形成は認められなかった.

実機でブリーチングの認められた第 1 断面では，本 シミュレーションの結果でもブリーチングが模擬でき ており，その他の部位ではブリーチングは認められて いないことから，本シミュレーション手法は，ほほ実 機の現象を再現することができたと考える.

$3 \cdot 2 \cdot 2$ ブリーチング形成の経時変化 調査に供 した翼の断面 1 の最高温部におけるブリーチングの形 成をシミュレーションした結果を Fig. 7 に示す．温度 勾配の設定は, $3 \cdot 2 \cdot 1$ 項と同様, $-9 \times 10^{5 \circ} \mathrm{C} / \mathrm{m}$ と した。なお，縦軸に示したブリーチングの形成密度は 以下のように定義した.

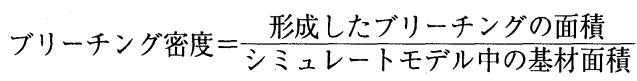
ここでは複数回繰返したシミュレーションの結果を示 しているが，良好な再現性を示しており，ブリーチン グの形成は時間にほほ比例することが確認できた。

$\mathrm{Al}$ の拡散にともない $\mathrm{Al}$ 濃度が平均化し, $\mathrm{Al}$ の拡散

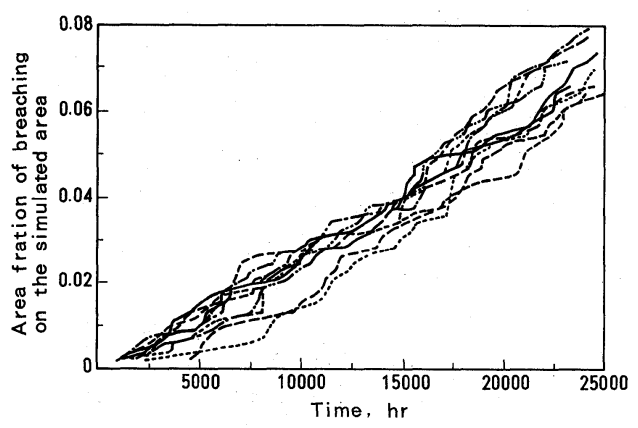

Fig. 7. Simulation results of breaching formation during the serviced time up to $25000 \mathrm{hr}$ at the section 1 . 


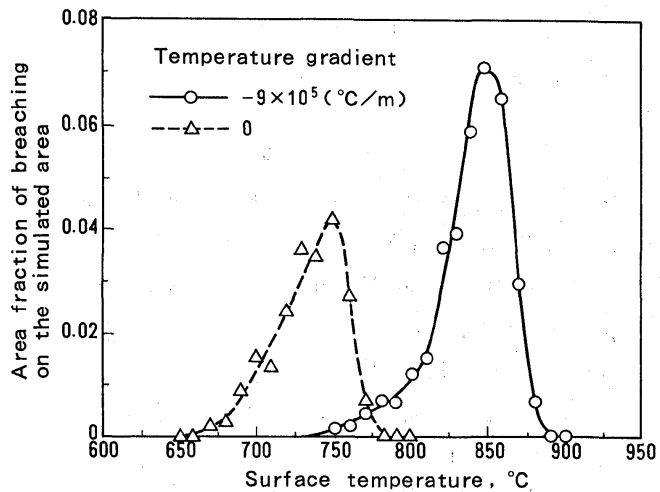

Fig. 8. Effects of surface temperature and temperature gradinet on the formation of breaching after the $25000 \mathrm{hr}$ service.

速度は低下する．この結果 Al クラスターの会合確率 は時間と共に低下するが, ブリーチングが形成するこ とにより Al の拡散の自由度は低下することから $\mathrm{Al}$ の凝集効果が現れる.この両者の効果がほぼ拮抗した ため時間に対する直線性が生じたものと考えられる.

$3 \cdot 2 \cdot 3$ ブリーチング形成に及ぼす温度勾配の影 響 拡散方向につけた温度勾配がブリーチングの形成 に及ぼす影響について検討した結果を Fig. 8 に示す. ここでは，温度勾配がない場合と $-9 \times 10^{5}{ }^{\circ} \mathrm{C} / \mathrm{m}$ の温 度勾配をつけた場合に，表面温度を変化させ，25000 hr 経過後のブリーチング密度の変化を調べている. 温度勾配がない場合には， $750^{\circ} \mathrm{C}$ 近傍にピーク值が認 められるのに対し, 温度勾配をつけた場合には, ピー クを示す表面温度が高温側にシフトしており, -9 $\times 10^{5} \mathrm{C} / \mathrm{m}$ の温度勾配では $850^{\circ} \mathrm{C}$ 近傍にそのピーク 值が認められた。ブリーチングの形成は表面から 110 $\mu \mathrm{m}$ 以上の染さで認められており,この部位は約 $750^{\circ} \mathrm{C}$ であることから，ブリーチングの形成は，これ が発生する基材部の温度に依存することを示している。

また，この図で明らかなように，温度勾配がある場 合は, 温度勾配がない場合より約 1.7 倍のピーク值を 示している。これは，ブリーチングの形成が，ブリー チングの形成する部位の温度に依存する形成確率で一 義的に決まるものでなく, Al クラスターの会合確率 との相乗で決まることによる. つまり, 温度勾配があ る場合，表面温度は高くなることから基材に流入する $\mathrm{Al}$ クラスターの量は多くなり会合確率は高くなるた めである。

$3 \cdot 2 \cdot 4$ ブリーチング形成の方位依存性 $\mathrm{X}$ 軸方 向と X 軸に $45^{\circ}$ の方向の形成確率を変えた場合のブ リーチングの形成形態の違いを検討した結果を Fig. 9 に示す. (a) は X 軸方向と X 軸に $45^{\circ}$ の方向の形成確 率比を $2 / 5$ とした場合を, (b) は $10 / 1$ と与えた場合を

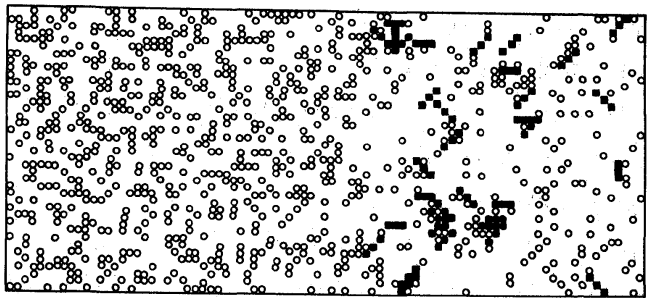

(a) X-Direction $/ 45^{\circ}-$ Direction $=2 / 5$

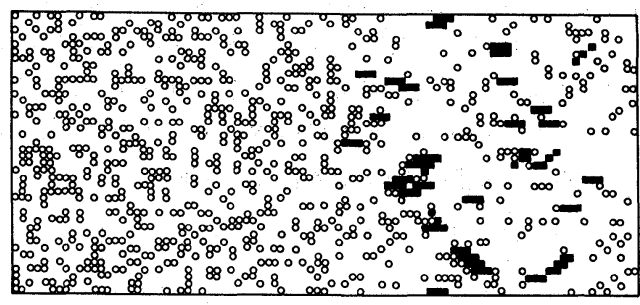

(b) $X$-Direction $/ 45^{\circ}-$ Direction $=10 / 1$

Fig. 9. Effect of formation probability on the morphology of breaching.

示している. (a)では $\mathrm{X}$ 軸方向の深さに拘らず X 軸に $45^{\circ}$ の方向のブリーチングが認められ, 深くなるに従 いX 軸方向の成長は認められなくなるのに対し，(b) は主として X 軸方向のブリーチングが生じており, $45^{\circ}$ 方向のブリーチングは基材からある深さの領域で のみ認められている. 実機のブリーチングの調査結果 は既にFig. $2(\mathrm{a})$ に示したが，この結果でみる限り， 実機はシミュレーショシ結果の (b) に類似している: このことから，実機ではブリーチングは X 軸方向に 優先的に形成したものと考えられる.このX 軸方向 は, $\mathrm{Al}$ クスタの拡散方向である。 また, 本供試材 においては凝固時のデンドライトの成長方向でもあり， 結晶方位としては〈001〉方向に相当する.ブリーチン グの形成がこの結晶方位に依存するのか，単に拡散方 向に依存するのか, あるいは形成確率の温度勾配方向 依存性によるものかは今後の検討課題としたい．

\section{4 結 言}

実機のコーティシグ層の損傷および劣化形態を調査 し，その劣化過程をシミュレートする手法についての 検討を行った. その結果, 実機で生じるコーティング 層の寿命を決める指標であるブリーチングの形成を，

$\mathrm{Al}$ クラスターの拡散モデルを用い, モンテカルロシ ミュレーションによりほぼ再現することができた。 今 後, さらに, 実機の温度分布の解析結果, 本材料系の 物理定数の計測結果, および劣化相形成の機構を解明 することにより，また，さらに実機デー夕の充実を図 ることにより，より実機条件に近い物理モデルの構築 を図り，精度よくコーティング層の寿命を予測できる 
技術の開発を推進したい:

主な結果をまとめ以下に示す。

（1）実機コーティング層の劣化形態を $\mathrm{Al}$ クラスタ 一の拡散モデルを用いたモンテカルロシミュレーショ ンにより再現することができた.

(2) このシミュレーションを用い解析した結果,

(a) ブリーチングが優先的に形成する温度域が認 められた。

(b) ブリーチングの形成に表面温度および温度勾 配依存性が認められた。温度勾配がある場合, この形成量がピークを示す表面温度は高温側に 移行し，また，量も多くなる傾向を示した.

(c) ブリーチングの形成確率に方位依存性が認め られ，拡散方向に最も高くなる傾向が認められ た.
(平成 4 年12月 3 日 日本材料学会第30回高温強度記念シンポジウムに て講演)

\section{参 考 文 献}

1 ) P. W. Schilke, A. D. Foster, J. J. Pepe, GE Turbine Reference Library, GER-3569A (1989).

2 ) W. Esser, B. Deblon, N. Czech, "Life assessment \& repair technology for combustion turbine hot section components", EPRI GS-7031, 313 (1990).

3 ) 吉岡洋明, 斉藤大蔵, 村上 格, 藤山一成, 岡部永年, 材料, 41，1724 (1992).

4 ) T. B. Massalski, "Binary Alloy Phase Diagrams", 142 (1986) ASM, Ohio

5 ) W. Gust, M. B. Hintz, A. Lodding, H. Odelius, and B. Predel, Phys. Stat. Solidi, A, 64, 187-94 (1981).

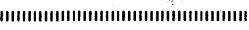

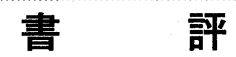

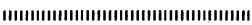

$$
\begin{gathered}
\text { “パーコレーションの科学” } \\
\text { 小田垣 孝 (著) }
\end{gathered}
$$

（1993年，(株) 裳華房発行，A 5 判，131ページ，2575円）

パーコレーションは，「浸透」を意味する用語であるが，1957年に Broadbent と Hammersley により，系内の 要素のつながりを一般化するための新しい概念として提唱されたものの呼称で，スケーリング理論，繰り込み群， 確率過程伝導等の多岐にわたる学問分野で応用され，長足の進歩を遂げている．さらら，近年のコンピュータの 発達とあいまって, 各種数值計算法やシミュレーション技術が著しく発展し，これらがパーコレーションの基礎 と応用に関する研究の推進に大きく貢献している.

本書は，この新しい概念について判り易く解説したもので，格子のパーコレーション，クラスター解析とスケ ーリング理論, 繰り込み群, 連続空間パーコレーション, 動的パーコレーション等について基本的な重要項目が, 系統的によくまとめられている，また，最後に，「成長過程と伝染病」「情報の伝ぱと局在」「高分子のゲル化」, 「インベージョンパーコレーション」など，いくつかの応用例についても詳細に紹介されており，この概念を現実 の問題に応用する場合の大きな指針を与えてくれる良書と思われる. なお, 本書は, 複数の大学で行われた集中 講義の講義ノートをもとに編集されたもので, 各章ごとに演習問題や解答も示されており, この分野の初学者に も読み易く，かつ前述のとおり基礎と応用の両面について，コンパクトに効率的な編集がなされている点は特筆 に価するものと思われる. 